\title{
Mechanisms of Lymphocytotoxicity Induced by Extracorporeal Photochemotherapy for Cutaneous T Cell Lymphoma
}

\author{
David I. Marks, Steven P. Rockman, Margaret A. Oziemski, and Richard M. Fox \\ Department of Haematology and Medical Oncology, Royal Melbourne Hospital, Post Office 3050, Victoria, Australia
}

\begin{abstract}
Extracorporeal photochemotherapy is an effective treatment for cutaneous $T$ cell lymphoma but its mode of action is uncertain. The reduction in viability of patients' photoirradiated buffy coat lymphocytes was correlated with a $35 \%$ increase in DNA single-strand breaks and marked decreases in cellular ATP and NAD levels (to 58 and 34\% of control, respectively) immediately after photoirradiation. Complementary in vitro studies were conducted with normal human peripheral blood lymphocytes using a Therakos ultraviolet A (UVA) light box. UVA light was cytotoxic on its own but was potentiated by 8-methoxypsoralen. 3-aminobenzamide, a poly (ADP-ribose) synthetase inhibitor, mitigated the cytotoxic effect of ultraviolet $A$ light in the presence of 8-methoxypsoralen in lymphocytes and reduced the amount of nucleotide depletion they caused. $10 \mathrm{~J} / \mathrm{cm}^{2}$ of UVA light in the presence of $300 \mathrm{ng} / \mathrm{ml}$ 8-methoxypsoralen increased the poly (ADP-ribose) synthetase activity of peripheral blood lymphocytes. Exposing lymphocytes to deoxycoformycin and deoxyadenosine was found to induce biochemical and physical effects similar to those of photochemotherapy. In summary, we have shown that the lymphocytotoxic effect of extracorporeal photochemotherapy for cutaneous $T$ cell lymphoma is apparently mediated by DNA damage, subsequent poly (ADP-ribosyl)ation and adenine nucleotide depletion. It is not known how the DNA damage and resultant biochemical effects relate to the possible immunological mechanism of extracorporeal photochemotherapy; however, it is possible that its effects can be mimicked by other DNA-damaging agents. (J. Clin. Invest. 1990. 86:20802085.) Key words: poly (ADP-ribosyl)ation • nucleotide depletion - DNA strand breaks • 8-methoxy-psoralen • deoxycoformycin
\end{abstract}

\section{Introduction}

Cutaneous $\mathrm{T}$ cell lymphoma (CTCL) ${ }^{1}$ is a malignant monoclonal proliferation of $\mathrm{T}$ lymphocytes usually of the helper pheno-

Address reprint requests to Dr. David Marks, Dept. of Haematology and Medical Oncology, Royal Melbourne Hospital, Post Office 3050, Victoria, Australia.

Received for publication 12 January 1990 and in revised form 7 May 1990.

1. Abbreviations used in this paper: CTCL, cutaneous T cell lymphoma; dAdo, deoxyadenosine; dCF, deoxycoformycin; ECPC, extracorporeal photochemotherapy; 8-MOP, 8-methoxypsoralen; \% D, percent double-stranded DNA remaining; SSBs, DNA single-strand breaks; 3-ABA, 3-aminobenzamide.

J. Clin. Invest.

(C) The American Society for Clinical Investigation, Inc.

0021-9738/90/12/2080/06 \$2.00

Volume 86, December 1990, 2080-2085 type (1). The diseases encompassed include Sezary syndrome, mycosis fungoides, and various adult $T$ cell leukemias. There are up to 10,000 new cases per year in the USA; it is more common in males and usually diagnosed after the age of 40 . It typically remains localized to the skin for a time, then evolves into a nonepidermotropic stage in which there is dissemination and involvement of other organ systems. Extracutaneous spread is associated with refractoriness to treatment and a poor prognosis.

Therapy for disseminated CTCL includes systemic chemotherapy, leukapheresis, and the use of monoclonal antibodies directed against the malignant lymphocyte phenotype. Oral 8-methoxypsoralen (8-MOP) photochemotherapy is effective in early stage skin-localized CTCL $(2,3)$. It produces few side effects, does not cross-react with other treatments, and results in relatively long-lived remissions. Its effects are limited to tissues exposed to ultraviolet A (UVA) because of the short half-life of the photoactive form of the drug.

In 1987, Edelson (4) described 37 patients with CTCL treated with "extracorporeal photochemotherapy" (ECPC). In this technique, following an oral dose of 8-MOP, patients were leukapheresed and their buffy coat lymphocytes extracorporeally exposed to UVA light for $3 \mathrm{~h}$, and then reinfused into the donor patient. $73 \%$ of all patients responded with a mean of $64 \%$ decrease in cutaneous involvement (skin score). Their median survival is now in excess of 4 yr (less than $50 \%$ of the 37 patients are now dead), greater than that for historical controls.

Psoralens are bifunctional photoreagents that form covalent bonds with pyrimidine bases of nucleic acids (5). They consist of a furan ring and a coumarin. Their planar structure enables them to intercalate into double-stranded nucleic acid and undergo covalent addition at either the furan or coumarin end. Photoaddition occurs with long wavelength UVA light $(320-400 \mathrm{~nm})$. The monoadducts and covalent interstrand crosslinks (diadducts) it forms are chemically stable. 8-MOP is absorbed orally reaching peak levels $1-4 \mathrm{~h}$ later and is almost entirely excreted by $24 \mathrm{~h}$. It has been reported that to exert a therapeutic effect the plasma 8-MOP level must exceed 50 $\mathrm{ng} / \mathrm{ml}$ during the period of UVA irradiation (4)

The mechanism of action of ECPC in CTCL is not well understood. There is evidence that when the damaged lymphocytes are returned to the patient they incite an immune reaction (4). In vitro studies showed that about $90 \%$ of these irradiated lymphocytes are nonviable at $96 \mathrm{~h}$. Detailed studies of the mechanism of this cytotoxicity have not been performed. The DNA damage that photoactivated psoralens cause is the presumed mechanism of cell death. DNA-damaging agents may kill cells by causing ATP and NAD depletion secondary to poly (ADP-ribosyl)ation at sites of DNA strand breakage (6): we postulated that this might be an important mechanism of the lymphocytotoxicity of CTCL cells treated with ECPC. We report studies with treated patients' buffy coat 
lymphocytes, complemented by in vitro experiments with PBL using a UVA light source and 8-MOP. We show the potentiation of UVA damage to lymphocyte DNA by 8-MOP and the correlation of cytotoxicity with subsequent adenine nucleotide depletion, apparently secondary to poly (ADP-ribosyl)ation.

\section{Methods}

Photopheresis procedure. All patients were treated with the UVAR photopheresis system (Therakos, Inc., West Chester, PA). This machine is the vehicle for the collection of buffy coat lymphocytes and also contains the clear plastic disposable cassette where lymphocytes are exposed to UVA light. At $0 \mathrm{~h}$, the patients ingested 8-MOP tablets at a dose of $0.6 \mathrm{mg} / \mathrm{kg}$. $1.5 \mathrm{~h}$ later, the patients were venipunctured and connected to the photopheresis machine. $15 \mathrm{~min}$ later when the first buffy coat sample $(40 \mathrm{ml})$ had been collected the UVA source was switched on to irradiate the buffy coat sample. Over the next 1.5-2 h (depending on the rate of venous blood flow) a further five buffy coat samples were collected. In total, there were six cycles of blood withdrawal, centrifugation, and reinfusion. Red cells and all additional plasma were returned to the patient before beginning the next collection cycle. At this stage (3.25-3.75 h after tablet ingestion) the final volume for photoirradiation was reached and the patient was disconnected from the machine. The final volume of $740 \mathrm{ml}$ consisted of 240 $\mathrm{ml}$ buffy coat, $300 \mathrm{ml}$ plasma, and $200 \mathrm{ml}$ heparinized normal saline. Photoactivation continued for another $1.5 \mathrm{~h}$. The hematocrit of the leukocyte-enriched blood was always less than $7 \%$ because red cells block leukocyte absorption of UV energy. The mean number of cells reinfused was $3.1 \times 10^{9}$ (range $1.26-4.9 \times 10^{9}$ ), which is about $25 \%$ of the total circulating numbers of lymphocytes.

Treatment policy and assessment of response. Patients were treated on 2 consecutive d every 4 wk for 6 mo, with treatment frequency modified according to clinical response. Disease progress was monitored by measurement of standardized skin scores (4), skin biopsies, and by regular clinical photographs. Briefly, all skin was graded from 0 to 4 , with 4 representing the most severe disease. This was then multiplied by the percentage of total surface area involved so the maximum possible score is 400 . Skin score assessments were made before the commencement of therapy and then monthly before each course of ECPC by an experienced dermatologist. Response was defined as a $25 \%$ improvement in the skin score, sustainable over a 1 -mo period. Complete reassessment of all patients occurred 6 mo after starting treatment.

Processing of buffy coat specimens. Specimens of buffy coat blood were obtained from the first buffy coat specimen and also after UV irradiation was complete, immediately before reinfusion to the patient. About $20 \mathrm{ml}$ of buffy coat blood was underlaid with $5 \mathrm{ml}$ of FicollHypaque and spun at $450 \mathrm{~g}$ for $25 \mathrm{~min}$. The cloudy mononuclear cell fraction was removed and counted. After washing in PBS the lymphocytes were resuspended in RPMI 1640 plus $10 \%$ FCS. After this handling, the mean composition of the cells $( \pm \mathrm{SE})$ was: lymphocytes $74 \pm 9 \%$, granulocytes (including band forms) $22 \pm 8 \%$, and monocytes $3 \pm 1 \%$.

Viability. For viability studies, lymphocytes from the buffy coat samples were suspended in RPMI 1640 plus $10 \%$ FCS and incubated at $37^{\circ} \mathrm{C}$. Viability was determined by the ability of cells to exclude $0.5 \%$ trypan blue. Viability was assessed every 24 to $96 \mathrm{~h}$ after photoirradiation and compared with the 24-96-h viabilities of the unirradiated buffy coat lymphocytes that were similarly handled.

Measurement of DNA single-strand breaks. About $1 \times 10^{7}$ lymphocytes were spun to form a pellet and then processed in triplicate samples according to the fluorometric method of Birnboim and Jevcak (7). The percentage of double-stranded DNA remaining (\% D) of the first (control) specimen was corrected to 100 and the $\% \mathrm{D}$ value obtained for the second specimen was expressed as a percentage of this. The increase in DNA single-strand breaks (SSBs) was calculated by subtracting the $\% \mathrm{D}$ value from 100 . The in vitro processing of lym- phocytes from normal human donors and their exposure to 8-MOP did not affect cellular viability; viability was unimpaired at the time of measuring DNA damage.

Measurement of NAD and ATP content. Approximately $2 \times 10^{7}$ lymphocytes were centrifuged to form a pellet, extracted with ice-cold perchloric acid, and their NAD and ATP content measured by HPLC as previously described (8). The lymphocytes obtained from the unirradiated buffy coat specimen were regarded as having normal (control) NAD and ATP content and the nucleotide content of the lymphocytes from the second specimen was calculated as a percentage of this control value.

Normal human peripheral blood lymphocytes. Fresh human peripheral lymphocytes were obtained by venesection or from normal human volunteers' buffy coat specimens (Victorian Red Cross Blood Bank, Victoria, Australia) which were available within $1 \mathrm{~h}$ of leukapheresis. The 40-ml buffy coat specimen was overlaid onto $5-10 \mathrm{ml}$ of Ficoll-Hypaque and spun at $450 \mathrm{~g}$ for $25 \mathrm{~min}$. Two washes in PBS were followed by suspension in RPMI 1640 plus $10 \%$ FCS and antibiotics.

UV irradiation of lymphocytes. For UV irradiation, cells were suspended in culture medium at about $5 \times 10^{5}$ cells $/ \mathrm{ml}$. 8-MOP was freshly made up from stock solutions $(1 \mathrm{mg} / \mathrm{ml})$ and was added to cells shielded from the light for at least $15 \mathrm{~min}$ before photoirradiation. $5-10-\mathrm{ml}$ aliquots of cell suspension were irradiated in $25-\mathrm{cm}^{2}$ plastic tissue culture flasks (Costar Data Packaging Corp., Cambridge, MA) with a Therakos research light box which contained a Photosette-R UVA light assembly mimicking the therapeutic equipment used for humans. Two banks of six lamps were located behind windows of transparent glass $10 \mathrm{~cm}$ apart. The lamps were operated at the maximum power setting of 10 for at least 10 min before experiments. The Commonwealth Scientific and Industrial Research Organization National Measurement Laboratory of Australia measured the ultraviolet irradiance in the center of the lower window as $31 \mathrm{~mW} / \mathrm{cm}^{2}$ (but only $20 \mathrm{~mW} / \mathrm{cm}^{2}$ in the periphery). A 32-s exposure therefore was equivalent to $1 \mathrm{~J} / \mathrm{cm}^{2}$ of energy. The center of the panel was used exclusively for UV irradiation.

Measurement of cellular poly (ADP-ribose) synthetase activity. To measure poly (ADP-ribose) synthetase levels, the method of Berger (9) was used, in which cells were rendered permeable to an exogenously supplied nucleotide and then the incorporation of $\left[{ }^{3} \mathrm{H}\right] \mathrm{NAD}$ into acidprecipitable material at $30^{\circ} \mathrm{C}$ was measured.

HPLC measurement of serum 8-MOP levels. Serum 8-MOP levels were measured according to the HPLC method of Puglisi (10). Blood samples were taken from all patients at hourly intervals during the period of photopheresis, so the peak 8-MOP level and its timing could be determined.

Materials. Aqueous liquid scintillant and $\left[{ }^{3} \mathrm{H}\right] \mathrm{NAD}(3 \mathrm{Ci} / \mathrm{mmol})$ were from Amersham International, Amersham, UK. Deoxycoformycin was provided by Parke-Davis, Morris Plains, NJ, and deoxyadenosine was from Sigma Chemical Co., St. Louis, MO. All other chemicals were from BDH Chemicals Ltd., Kilsyth, Victoria, Australia. Details of the materials for HPLC measurement of nucleotides and the fluorometric assay of DNA SSBs have been described previously (Marks, D. I., and R. M. Fox, submitted for publication).

\section{Results}

Clinical response to extracorporeal photochemotherapy. Four patients with CTCL (three males and one female, mean age of 69) were treated with ECPC. Patients received 16-25 courses (mean 19) over a mean period of $25 \mathrm{wk}$. One patient died 7.5 mo after the commencement of treatment of myocardial infarction and pulmonary embolism. The four patients had significant palliation of their disease. The mean maximum decrease in skin score was $41 \%$ (range $29-55 \%$, Table I).

Effects of extracorporeal photochemotherapy on lymphocyte viability. To assess the effect of the ECPC procedure on the patients' harvested lymphocytes, trypan blue viability was 
Table I. Clinical and Biochemical Data about Four Patients with CTCL

\begin{tabular}{|c|c|c|c|c|c|c|c|}
\hline Patient No. & $\begin{array}{l}\text { Initial skin } \\
\text { score }\end{array}$ & $\begin{array}{l}\text { Minimum skin } \\
\text { score }\end{array}$ & MDSS & $\begin{array}{l}\text { Mean increase } \\
\text { DNA SSBs }\end{array}$ & $\begin{array}{l}\text { 24-hour } \\
\text { viability }\end{array}$ & $\begin{array}{c}\text { Mean NAD } \\
\text { content* }\end{array}$ & $\begin{array}{c}\text { Mean ATP } \\
\text { content }\end{array}$ \\
\hline & & & $\%$ & $\%$ & $\%$ & $\%$ & $\%$ \\
\hline 1 & 253 & 154 & 39 & 9 & 71 & $\mathrm{ND}^{\ddagger}$ & 48 \\
\hline 2 & 345 & 208 & 40 & 32 & 44 & 24 & 66 \\
\hline 3 & 336 & 237 & 29 & 60 & 16 & 33 & 83 \\
\hline 4 & 181 & 81 & 55 & 39 & 53 & 44 & 34 \\
\hline Mean & 279 & 170 & 41 & 35 & 46 & 34 & 58 \\
\hline
\end{tabular}

* The NAD and ATP contents of buffy coat cells were measured immediately after photoirradiation. DNA SSBs were measured immediately after photoirradiation by the fluorometric unwinding method (see Methods). ${ }^{\ddagger}$ Not determined.

studied daily for $4 \mathrm{~d}$ following the procedure. This was studied in nine patient samples (from nine different treatment cycles) from the four patients. Viability progressively declined over several days, at a rate similar to that reported by Edelson (4). Less than $5 \%$ of the treated cells were viable at $96 \mathrm{~h}$ (Table II).

DNA single-strand breaks. To explore the mechanism of action of the ECPC-induced in vitro lymphocytotoxicity, DNA damage was assessed. Although other forms of DNA damage may have been induced by the UVA/8-MOP, DNA single strand breaks were assayed by the fluorometric technique. DNA damage was assessed in samples of buffy coat lymphocytes after photoirradiation just before reinfusion into the patient. The viability of photoirradiated cells at the time of measuring DNA SSBs was the same as nonphotoirradiated control cells $(85 \%)$. The control \% D value for nonphotoirradiated lymphocytes was corrected to $100 \%$ and the treated lymphocyte sample expressed as a percentage of this. The absolute control \% D value for the patients' cells (and for normal PBL) was 79 (range 60-97). All samples assessed had a marked increase in DNA SSBs (Table I) but the extent of damage varied considerably among different patients, ranging from 9 to $60 \%$. DNA damage was assessed twice in all except patient 3 . There was $<15 \%$ variation between readings from samples at different time points; only the mean is stated. There was no correlation between the number of malignant cells and the percentage of DNA SSBs.

Adenine nucleotide content. In view of the apparent association between DNA damage and lymphocytotoxicity, the ex-

Table II. Effect of Extracorporeal Photochemotherapy on Lymphocyte Viability

\begin{tabular}{lcc}
\hline Lymphocyte sample & Control viability & SE \\
\hline & $\%$ & \\
Control & 100 & 5 \\
24 h postECPC & 56 & 9 \\
48 h postECPC & 30 & 5 \\
96 h postECPC & 3 & 1
\end{tabular}

Samples were taken from patients' buffy coat collections before (control) and after photoirradiation, then placed in RPMI 1640 plus $10 \%$ FCS, and trypan blue viability measured for the next $96 \mathrm{~h}$. The results shown represent the mean of nine patient samples from four patients. The mean control cell viability after exposure to 8-MOP and processing was $85 \%$. tent of ATP and NAD depletion, possibly secondary to poly (ADP-ribosyl)ation, was investigated. Eight patient samples of immediate postirradiation buffy coat lymphocytes (eight treatment cycles) from four different patients were analyzed. NAD content was measured in three of the four patients. All lymphocyte samples assessed showed depletion of nucleotides. The decline in NAD content was much more marked than the fall in ATP content (Table I). The fall in the nucleotide content of patients' lymphocytes did not correlate with the degree of DNA damage to them. Absolute control NAD and ATP content (in patients' and normal PBL) were 60 (48-74) and 202 (180-220) pmol/106 lymphocytes, respectively.

Correlation of biochemical parameters with clinical response. The biochemical and physical damage to buffy coat lymphocytes demonstrated above from CTCL patients has not been previously documented nor correlated with the clinical response of CTCL to ECPC. Four patients with CTCL were evaluable for response (Table I). This number of patients precludes a meaningful statistical analysis of the relationship between response and the parameters of cell injury or death. However, the percentage of DNA SSBs was strongly associated with the decline in cellular viability (simple regression analysis, $R^{2}=0.877$, Fig. 1). There was no correlation between the number of cells a patient had reinfused and that patient's clinical response (maximum decrease in skin score) (MDSS, data not shown).

Serum 8-MOP levels. The 8-MOP levels of all patients were found to exceed $50 \mathrm{ng} / \mathrm{ml}$ during the entire period of photopheresis. The mean peak level was $168 \mathrm{ng} / \mathrm{ml}$ and occurred at an average of $2 \mathrm{~h}$ after ingestion. Peak serum 8-MOP levels did not correlate with clinical response, in vitro lymphocytotoxicity or with any of the biochemical parameters associated with cell death.

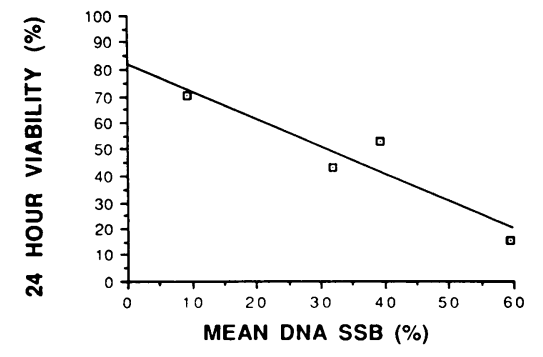

Figure 1. Percent increase in DNA single strand breaks vs. percent decrease in cellular (trypan blue) viability. Simple regression analysis yields an $R^{2}$ of 0.877 . The intercept for the graph is 82.1 (38.9$125.2,95 \%$ confidence limits) and the gradient is $-1.03(-2.12-0.06)$. 
In vitro experiments on the mechanisms of 8-MOP and $U V A$ photochemotherapy-induced cytotoxicity in $P B L$. Sham photochemotherapy treatment experiments were conducted with peripheral blood lymphocytes from normal blood bank volunteers. These experiments enabled variation of the intensity of UVA light, the concentration of 8-MOP, and the interaction between 8-MOP and UVA light to be studied in an attempt to elucidate the mechanism of lymphocytotoxicity.

Viability. Control experiments revealed that 8-MOP alone (without UV irradiation) was not toxic to PBL: $10-300 \mathrm{ng} / \mathrm{ml}$ did not affect corrected viability after $72 \mathrm{~h}$ incubation at $37^{\circ} \mathrm{C}$. The effect on lymphocyte viability of a wide range of doses of UVA light $\left(0.1-10 \mathrm{~J} / \mathrm{cm}^{2}\right)$ was studied: the results for 1 and 2 $\mathrm{J} / \mathrm{cm}^{2}$ (the dose given to patients) are shown in Fig. $2 \mathrm{~A}$. The addition of 8-MOP clearly potentiated the cytotoxicity caused by UVA light; however, the potentiating effect was dependent on the dose of UVA light. At doses of $3 \mathrm{~J} / \mathrm{cm}^{2}$ and above there was minimal potentiation (data not shown), while at 1-2 $\mathrm{J} / \mathrm{cm}^{2}$ the potentiation was marked. 8-MOP concentrations higher than $50 \mathrm{ng} / \mathrm{ml}$ did not further increase cytotoxicity in PBL (data not shown).

Many cytotoxic agents that are thought to mediate their cytotoxic effect via poly (ADP-ribosyl)ation have their cytotoxicity reduced (or completely eliminated) by the addition of specific poly (ADP-ribose) synthetase inhibitors. The addition of 3-aminobenzamide (ABA) ( $2 \mathrm{mM}$ ), a dose sufficient to inhibit poly (ADP-ribose) synthetase but which did not affect lymphocyte viability, decreased the cytotoxic effect of exposing PBL to $2 \mathrm{~J} / \mathrm{cm}^{2}$ UVA and $300 \mathrm{ng} / \mathrm{ml}$ 8-MOP. This dose of 8-MOP was chosen to maintain an excess of the drug. The

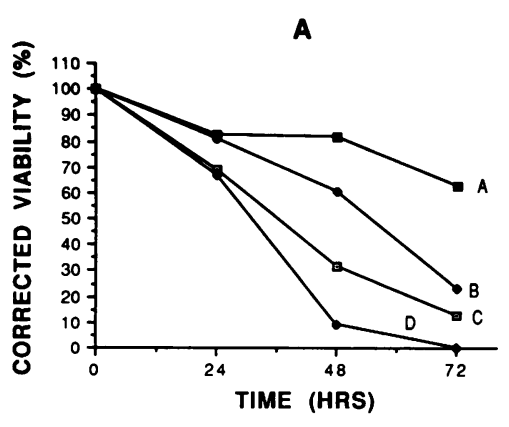

Figure 2. Effects on viability. ( $A$ ) PBL were exposed to UVA light $\left(1-2 \mathrm{~J} / \mathrm{cm}^{2}\right)$ with or without 8-MOP (300 $\mathrm{ng} / \mathrm{ml}$ ) and their corrected viability determined by trypan blue exclusion every $24 \mathrm{~h} . A$ $1 \mathrm{~J} / \mathrm{cm}^{2}$ UVA; $B, 1$ $\mathrm{J} / \mathrm{cm}^{2}$ UVA + 8-MOP; $C, 2 \mathrm{~J} / \mathrm{cm}^{2} \mathrm{UVA} ; D, 2$ $\mathrm{J} / \mathrm{cm}^{2}$ UVA + 8-MOP. Mean of triplicate samples from a representative experiment (with multiple replicate experiments). (B) PBL were exposed to UVA light $\left(2 \mathrm{~J} / \mathrm{cm}^{2}\right)$ and 300 $\mathrm{ng} / \mathrm{ml}$ 8-MOP with or without $2 \mathrm{mM}$ 3-ABA and corrected viability was determined at 24 and $48 \mathrm{~h}$. This is compared with incubating PBL with 2 mM 3-ABA TIME (HRS) alone. $A, 3-\mathrm{ABA}$ alone; $B, 2 \mathrm{~J} / \mathrm{cm}^{2} \mathrm{UVA}+8$-MOP; $C, 2 \mathrm{~J} / \mathrm{cm}^{2} \mathrm{UVA}$
+8 -MOP + 3-ABA. The data represent the results (performed in triplicate) from a typical sample. Multiple replicate experiments show the same pattern. The two figures represent experiments involving PBL from different donors. Control lymphocyte viability was $92 \%$. viability of the 3-ABA and UVA/8-MOP treated cells $(99 \%$ at $48 \mathrm{~h}$ ) was significantly different from the control UVA/8-MOP group $(61 \%, P<0.001)$ (Fig. $2 B$ ). The protective effect occurred whether the 3-ABA was added before or after irradiation; this excludes the possibility that 3-ABA mitigated the cytotoxic effect merely by decreasing the dose of UVA received by the PBL.

DNA damage. The DNA damage for a range $\left(1-5 \mathrm{~J} / \mathrm{cm}^{2}\right)$ of UVA light doses was studied $2 \mathrm{~h}$ after irradiation (Fig. 3). The DNA-damaging effects of UVA light on PBL was potentiated by the addition of 8-MOP. However, the extent of this potentiating effect was dependent on the dose of UVA light and the timing of the assay. Edelson (4) reported that the dose of UVA light delivered to his patients' buffy coat lymphocytes was 1-2 $\mathrm{J} / \mathrm{cm}^{2}$; we have shown that in vitro this was the dose where 8-MOP maximally potentiated the DNA damage caused by UVA light. In the sham experiments this dose induced a level of DNA strand breaks similar in extent to those in the patients' samples. At $1.5 \mathrm{~J} / \mathrm{cm}^{2} 8-\mathrm{MOP}$ increased the number of DNA SSBs by more than twofold. There was far less damage at $24 \mathrm{~h}$ $(<15 \%$ increase in DNA SSBs) than there was at $2 \mathrm{~h}$, presumably reflecting DNA repair (data not shown). $5 \mathrm{~J} / \mathrm{cm}^{2}$ of UVA light caused only slightly more DNA SSBs than $2 \mathrm{~J} / \mathrm{cm}^{2}$ : this suggests a ceiling effect.

Nucleotide content. Exposures of PBL to $1-40 \mathrm{~J} / \mathrm{cm}^{2}$ UVA light alone caused a nonlinear dose-dependent depletion of NAD and ATP $2 \mathrm{~h}$ after exposure (Fig. $4 \mathrm{~A}$ ). Between 1 and 10 $\mathrm{J} / \mathrm{cm}^{2}$ there was a steep increase in nucleotide depletion with further depletion only occurring at very high doses of UVA light. 8-MOP potentiated the NAD-depleting effects of UVA light alone. A $1 \mathrm{~J} / \mathrm{cm}^{2}$ UVA light exposure depleted PBL of $11 \%$ of their NAD content; adding $8-\mathrm{MOP}(300 \mathrm{ng} / \mathrm{ml})$ increased the total NAD depletion to $34 \%$ (representative experiment, mean of five observations). At higher UVA doses (2-10 $\mathrm{J} / \mathrm{cm}^{2}$ ) this potentiating effect was not apparent (data not shown). The addition of 8-MOP to $1-2 \mathrm{~J} / \mathrm{cm}^{2}$ UVA light did not further increase ATP depletion.

$2 \mathrm{mM}$ 3-ABA also mitigated the nucleotide depletion caused by $10 \mathrm{~J} / \mathrm{cm}^{2}$ of UVA light and continuous exposure to $300 \mathrm{ng} / \mathrm{ml}$ 8-MOP (Fig. 4 B). This dose of UVA light was chosen because it caused substantial NAD and ATP depletion; therefore, the mitigating effect of 3-ABA could be clearly demonstrated.

Poly (ADP-ribose) synthetase activity. PBL were exposed to $10 \mathrm{~J} / \mathrm{cm}^{2}$ UVA light in the presence of $300 \mathrm{ng} / \mathrm{ml} 8-\mathrm{MOP}$; at 2 h poly (ADP-ribose) synthetase activity rose to $160 \%$ of control (three experiments of three to five samples). Significant elevations in enzyme activity were not demonstrable with lower doses of UVA light. 8-MOP alone $(300 \mathrm{ng} / \mathrm{ml})$ did not affect

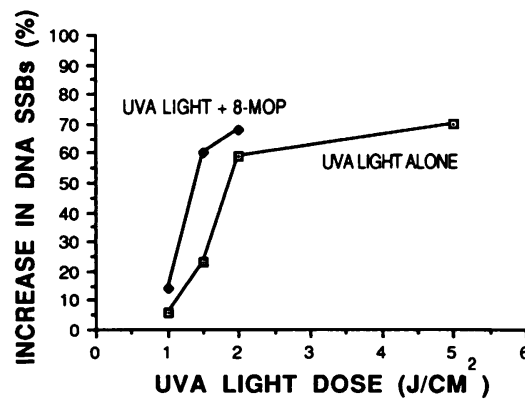

Figure 3. DNA damage. PBL were exposed to UVA light (1-5 J/ $\left.\mathrm{cm}^{2}\right)$ with or without 8-MOP $(300 \mathrm{ng} / \mathrm{ml})$ and the percent increase in DNA single strand breaks was measured 2 $\mathrm{h}$ later fluorometrically. Mean of two experiments each in duplicate. 
A

B

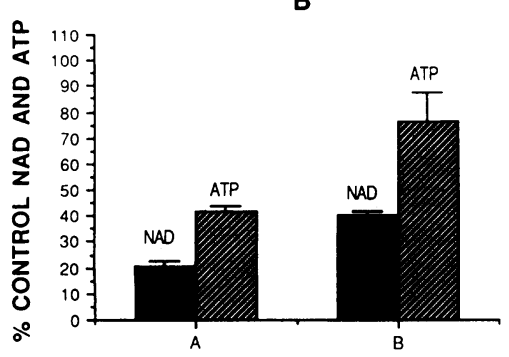

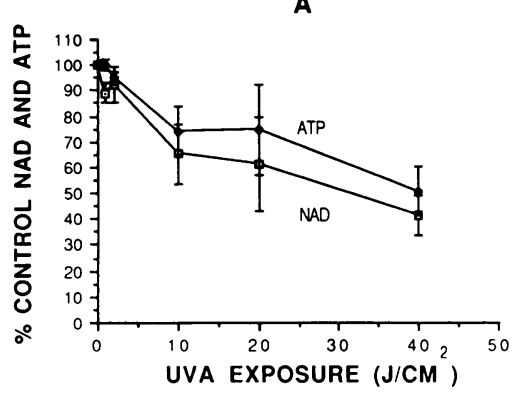

Figure 4. Effects on nucleotide content. $(A)$ PBL were exposed to UVA light (1-40 $\mathrm{J} / \mathrm{cm}^{2}$ ), then $2 \mathrm{~h}$ later extracted with perchloric acid and their NAD and ATP content measured by HPLC (Methods). Error bars indicate standard error of 3-4 observations. (B) PBL were exposed to UVA light $\left(2 \mathrm{~J} / \mathrm{cm}^{2}\right)$ in the presence of 300 $\mathrm{ng} / \mathrm{ml}$ 8-MOP with $B$, or without, $A, 2 \mathrm{mM}$ 3-ABA and $2 \mathrm{~h}$ later their NAD and ATP content (percent control) were measured. Error bars indicate the SE of three to four observations.

poly (ADP-ribose) synthetase activity $2 \mathrm{~h}$ after exposure. 10 $\mathrm{J} / \mathrm{cm}^{2}$ UVA light alone raised enzyme activity to $156 \%$ of control (two experiments of three samples). Control lymphocyte poly (ADP-ribose) synthetase activity was $1.20 \mathrm{pmol}$ $\min ^{-1}\left(10^{6} \text { cells }\right)^{-1}$.

Comparison between photochemotherapy and deoxyadenosine lymphocytotoxicity. Deoxycoformycin and deoxyadenosine lymphocytotoxicity has been previously shown to be associated with DNA damage and adenine nucleotide depletion presumably secondary to stimulation of poly (ADP-ribosyl)ation (11). A 4-h exposure of PBL to $1 \mu \mathrm{M}$ deoxycoformy-
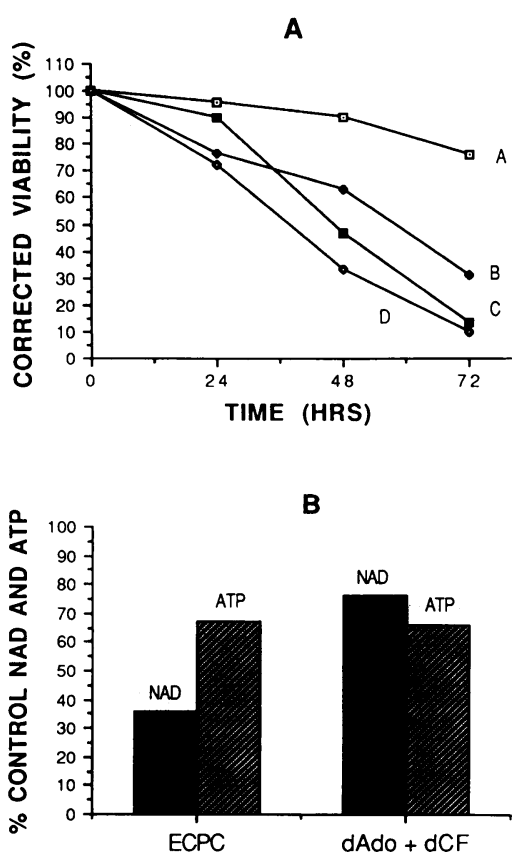

Figure 5. Comparison between photochemotherapy and deoxycoformycin and deoxyadenosine. $(A) \mathrm{PBL}$ were exposed to $1 \mu \mathrm{M}$ $\mathrm{dCF}$ and 0-20 $\mu \mathrm{M}$ dAdo for $4 \mathrm{~h}$ and corrected viability was determined for the next 72 h. $A, 1 \mu \mathrm{M} \mathrm{dCF} ; B$, $1 \mu \mathrm{M} \mathrm{dCF}+5 \mu \mathrm{M}$ dAdo; $C, 1 \mu \mathrm{M} \mathrm{dCF}$ $+10 \mu \mathrm{M}$ dAdo; $D, 1$ $\mu \mathrm{M} \mathrm{dCF}+20 \mu \mathrm{M}$ dAdo. Mean of three observations. (B) $2 \mathrm{~h}$ after a 4-h exposure to $1 \mu \mathrm{M} \mathrm{dCF}$ and $10 \mu \mathrm{M}$ dAdo, cellular NAD and ATP levels were determined (mean of two experiments). These are compared with the nucleotide depletion of lymphocytes caused by ECPC (Results). cin (dCF) and $10 \mu \mathrm{M}$ deoxyadenosine (dAdo) caused $85 \%$ cell death in $72 \mathrm{~h}$ (Fig. $5 \mathrm{~A}$ ), comparable to the delayed lymphocytotoxicity caused by ECPC. $2 \mathrm{~h}$ after drug exposure there was a $19 \%$ increase in DNA SSBs. At this time ATP was $66 \%$ of control levels and NAD 76\% of control (Fig. $5 \mathrm{~B}$ ): this is compared to the ex vivo effects of ECPC on lymphocytes from CTCL patients. dCF and dAdo caused comparable ATP depletion but less decrease in NAD.

\section{Discussion}

This study has documented the relationship between cytotoxicity and the biochemical and physical changes that occur in lymphocytes from patients with CTCL treated ex vivo with photochemotherapy. Photoactivated psoralens-induced DNA damage to cells has been well documented (5) but the way in which this DNA damage resulted in cell death was uncertain. Our studies of the effects of ECPC on buffy coat lymphocytes from patients with CTCL were complemented by in vitro experiments with PBL using a UVA light source that mimicked the effect of photochemotherapy.

Although UVA light caused DNA strand breaks on its own, there was clear evidence that 8-MOP can potentiate the damage caused by UVA light. The degree of this potentiation was highly dependent on the dose of UVA light. At doses of 3 $\mathrm{J} / \mathrm{cm}^{2}$ and above potentiation was minimal: UVA light alone caused most of the damage. However, when the dose of UVA light was $1 \mathrm{~J} / \mathrm{cm}^{2}$, the addition of 8-MOP significantly increased the degree of cell kill, the NAD depletion, and the number of DNA SSBs UVA light produced. The maximum potentiation of DNA damage by 8-MOP occurred at 1.5 $\mathrm{J} / \mathrm{cm}^{2}$. These observations provide the in vitro rationale for using $1-2 \mathrm{~J} / \mathrm{cm}^{2}$ as the dose of UVA light delivered to buffy coat lymphocytes in the clinical situation. Our four patients had a $41 \%$ mean increase in DNA SSBs suggesting that 1-2 $\mathrm{J} / \mathrm{cm}^{2}$ of UVA light was the dose delivered to them. It is also noteworthy that, even with lethal doses $\left(2 \mathrm{~J} / \mathrm{cm}^{2}\right)$ of UVA light and 8-MOP, the DNA damage present at $2 \mathrm{~h}$ was much greater than that at $24 \mathrm{~h}$ after exposure. It appears that this early DNA damage caused a series of biochemical events that irreversibly damaged the cell and that subsequent DNA repair did not affect this.

This UVA/8-MOP-associated DNA damage is associated with adenine nucleotide depletion. This study also presents some evidence that stimulation of poly (ADP-ribosyl)ation and consequent nucleotide depletion are involved in the lymphocytotoxic effect of photoactivated psoralens. Photoirradiation in the presence of 8-MOP caused significantly elevated levels of poly (ADP-ribose) synthetase activity. However, elevated enzyme activity levels were only found at high doses (10 $\mathrm{J} / \mathrm{cm}^{2}$ ) of UVA light. The failure to demonstrate elevated enzyme levels at $1-2 \mathrm{~J} / \mathrm{cm}^{2}$ may be due to the insensitivity of the assay or may reflect the transient nature of the rise in enzyme activity. The poly (ADP-ribose) synthetase inhibitor, 3-ABA, mitigated the cytotoxicity of photoirradiation and reduced the nucleotide depletion it caused. These three pieces of data are regarded as important evidence for the involvement of poly (ADP-ribosyl)ation (11). Poly (ADP-ribosyl)ation accounts for the majority of NAD turnover in the lymphocyte: it would appear to be the most likely cause for the changes in NAD content that we have demonstrated. 
A degree of caution is required in the interpretation of the correlations between clinical response and various biochemical parameters. The number of patients was small and although response correlated with ATP depletion it did not correlate with other parameters of cell kill.

In vitro studies in which normal PBL were treated with $\mathrm{dCF}$ and dAdo showed many similarities with the effects of ECPC on lymphocytes of patients with CTCL. The rate of cell kill, DNA strand breakage and extent of NAD and ATP depletion were all similar. Carson (12) originally demonstrated that dAdo and dCF caused DNA strand breaks, depleted cells of NAD and ATP, and increased levels of poly (ADP-ribose) synthesis. He found that nicotinamide and 3-ABA protected against these changes. We have shown that photoirradiation is also apparently associated with stimulation of poly (ADP-ribosyl)ation. Although 3-ABA can prevent adenine nucleotide depletion, it appears the biochemical damage to cells is irreversible (13).

It appears that photochemotherapy may have an immunologic mechanism of action. First, the superiority of ECPC to simple leukapheresis is evidence that reinfusion of the damaged (dying) cells is important. Delayed death of the reinfused, damaged lymphocytes may be important; there may need to be sufficient time for them to excite an immunological response in patients with CTCL. Second, immunocompetent patients respond better than those with impaired immunity (4). Third, there is a reduction in malignant cells in the skin (cells that have not been exposed to ECPC) that suggests they have been eradicated by a mechanism of host origin (4). It has been postulated that the reinfused damaged cells induce the proliferation of lymphocytes bearing antiidiotypic receptors that recognize the malignant clone.

We have shown the increased expression of various activation markers by lymphocytes from CTCL patients soon after treatment with ECPC (14). The UVA/8-MOP-induced changes in the reinfused peripheral blood lymphocytes may induce antigenic changes in their cell surface membranes, which might be responsible for this immune stimulation.

The practical implications of the findings in this report are that the extracorporeal treatment of patients' buffy coat with a combination of dAdo plus dCF (or other lymphocytotoxic agents) may achieve similar effects to ECPC. This is of some importance when the potential wider application of ECPC to autoimmune disease is considered. Replacement of ECPC by exposure of the buffy coat specimens to conventional DNAdamaging agents would be far more convenient. To test this hypothesis further we are conducting studies comparing infusions of photochemotherapy-affected and cytotoxic drug-damaged splenocytes as treatment of an animal autoimmune model of disease.

\section{Acknowledgments}

Dr. Marks is the recipient of a National Health and Medical Research Council (Australia) postgraduate fellowship. Assistance was also received from the NHMRC of Australia and the Anti-Cancer Council of Victoria.

\section{References}

1. Knobler, R. M., and R. L. Edelson. 1986. Cutaneous T-cell lymphoma. Med. Clin. North Am. 70:109-138.

2. Anderson, T. F., and J. J. Voorhees. 1980. Psoralen photochemotherapy of cutaneous disorders. Annu. Rev. Pharmacol. Toxicol. 20:235-237.

3. Gilchrest, B. A., J. Parrish, L. Tanenbaum, H. A. Haynes, and T. B. Fitzpatrick. 1976. Oral methoxsalen photochemotherapy of mycosis fungoides. Cancer (Phila.). 38:683-689.

4. Edelson, R., C. Berger, F. Gasparro, B. Jegasothy, P. Heald, B. Wintroub, E. Vonderheid, R. Knobler, K. Wolff, G. Plewig, et al 1987. Treatment of cutaneous T-cell lymphoma by extracorporeal photochemotherapy. N. Engl. J. Med. 316:297-303.

5. Cimino, G. D., H. B. Gamper, S. T. Isaacs, and J. E. Hearst. 1985. Psoralens as photoactive probes of nucleic acid structure and function: organic chemistry, photochemistry and biochemistry. Annu. Rev. Biochem. 54:1151-1193.

6. Berger, N. A. 1985. Symposium: cellular response to DNA damage: the role of poly (ADP-ribose). Radiat. Res. 101:4-15.

7. Birnboim, H. C., and J. J. Jevcak. 1981. Fluorometric method for rapid detection of DNA strand breaks in human white blood cells produced by low doses of radiation. Cancer Res. 41:1889-1892.

8. Crescentini, G., and V. Stocchi. 1984. Fast reversed phase high performance liquid chromatographic determination of nucleotides in red blood cells. J. Chromatogr. 290:393-399.

9. Berger, N. A., G. Weber, and A. S. Kaichi. 1978. Characterisation and comparison of poly (adenosine diphosphoribose) synthesis and DNA synthesis in nucleotide-permeable cells. Biochim. Biophys. Acta. 519:87-104.

10. Puglisi, C. V., A. J. de Silva, and J. C. Meyer. 1977. Determination of 8-methoxypsoralen, a photoactive compound, in blood by high pressure liquid chromatography. Anal. Lett. 10:39-50.

11. Althaus, F. R., and C. Richter. 1987. ADP-ribosylation of proteins. Enzymology and biological significance. Mol. Biol. Biochem. Biophys. 37:1-237.

12. Carson, D. A., S. Seto, D. B. Wasson, and C. J. Carrera. 1986. DNA strand breaks, NAD metabolism and programmed cell death. Exp. Cell Res. 164:273-281.

13. Ganeshaguru, K., A. Piga, L. Latini, and A. V. Hoffbrand. 1989. Inability of poly-ADP-ribosylation inhibitors to protect peripheral blood lymphocytes from the toxic effects of ADA inhibitors. $A d v$. Exp. Med. Biol. 253B:251-258.

14. Rockman, S. P., E. J. Wilde, M. A. Oziemski, G. Varigos, M. D. Green, and R. M. Fox. 1989. Immunological changes in patients receiving 8-methoxypsoralen and extracorporeal photochemotherapy for cutaneous T-cell lymphoma. Proc. Haematology Soc. of Australia, Adelaide. 1:54. (Abstr.) 